\title{
Arsenic trioxide re-sensitizes ER $\alpha$-negative breast cancer cells to endocrine therapy by restoring ER $\alpha$ expression in vitro and in vivo
}

\author{
WEIJIE ZHANG $^{1 *}$, LIUXING WANG $^{1 *}$, QINGXIA FAN $^{1}$, XINAI WU ${ }^{1}$, FENG WANG $^{1}$, \\ RUI WANG ${ }^{1}$, ZHIJUN MA ${ }^{1}$, JIANHUA YANG ${ }^{1}$ and SHIH HSIN LU ${ }^{1,2}$
}

\author{
${ }^{1}$ Department of Oncology, the First Affiliated Hospital of Zhengzhou University, ErQi District, Zhengzhou 450052; \\ ${ }^{2}$ Cancer Institute and Hospital, Chinese Academy of Medical Sciences, Chaoyang District, Beijing 100021, P.R. China
}

Received March 10, 2011; Accepted April 27, 2011

DOI: 10.3892/or.2011.1352

\begin{abstract}
Approximately one-third of breast cancers lack estrogen receptor $\alpha(\mathrm{ER} \alpha)$ because of the hypermethylation of the $\mathrm{CpG}$ island in the receptor's promoter. These tumors are associated with poorer histological differentiation, a higher growth fraction, are rarely responsive to endocrine therapy and have a worse clinical outcome. Thus, re-expression of ER $\alpha$ in ER $\alpha$-negative breast cancers may restore the sensitivity of antiestrogen therapy. The ER $\alpha$-negative breast cancer cell line MDA-MB-435s was treated with different concentrations of arsenic trioxide $\left(\mathrm{As}_{2} \mathrm{O}_{3}\right)$. MS-PCR was used to detect the change in the methylation status of ER $\alpha$. RT-PCR, immunohistochemistry and Western blot analyses were used to detect changes in the mRNA and protein expression of DNA methyltransferase-1 (DNMT1) and ER $\alpha$. Cell proliferation was examined using the MTT assay. A xenograft model in nude mice was used to further examine the results we observed in vitro. The ER $\alpha$ gene was demethylated after $\mathrm{As}_{2} \mathrm{O}_{3}$ treatment of MDA-MB-435s cells. RT-PCR, immunohistochemistry and Western blot analyses revealed that DNMT1 expression was inhibited and ER $\alpha$ was re-expressed in a concentrationdependent manner after $\mathrm{As}_{2} \mathrm{O}_{3}$ treatment. The MTT assay showed that cell proliferation was significantly suppressed after exposure to different concentrations of $\mathrm{As}_{2} \mathrm{O}_{3}$. Addition of tamoxifen (TAM) further suppressed levels of cell proliferation. In vivo, the xenograft tumor volumes of $\mathrm{As}_{2} \mathrm{O}_{3}$-treated mice were smaller than those observed in untreated and TAM-treated mice. Treatment with a combination of $\mathrm{As}_{2} \mathrm{O}_{3}+$ TAM resulted in further suppression. $\mathrm{As}_{2} \mathrm{O}_{3}$ can act as a demethylation agent
\end{abstract}

Correspondence to: Dr Shih Hsin Lu, Cancer Institute and Hospital, Chinese Academy of Medical Sciences, 17 South Panjiayuan, Chaoyang District, Beijing 100021, P.R. China

E-mail: shlu1212@gmail.com

*Contributed equally

Key words: arsenic trioxide, estrogen receptor $\alpha$, breast cancer, DNA methyltransferase-1, tamoxifen to restore $\mathrm{ER} \alpha$ expression in ER $\alpha$-negative breast cancer cells and re-sensitize these cells to endocrine therapy in vitro and in vivo.

\section{Introduction}

Among women in the developed world, breast cancer is the leading cause of cancer and the second leading cause of cancerrelated deaths. The American Cancer Society estimates that in 2010, 207,090 new breast cancer cases (accounting for $28 \%$ of all new cancer cases) and 39,840 deaths (accounting for $15 \%$ of all cancer-related deaths) in women will be reported in the USA alone (1). Experimental, clinical and epidemiologic data suggest that estrogens bind to the estrogen receptor (ER $\alpha$ or ER $\beta$ ) and stimulate the transcription of target genes involved in cell proliferation, which contribute to the development of breast cancer (2). ER $\alpha$ has a greater affinity for estrogen and is associated with comparatively higher levels of transcriptional activity (3). Clinically, the presence or absence of ER $\alpha$ in breast tumors is an important prognostic indicator of the disease. The presence of ER $\alpha$ correlates with increased disease-free survival and an overall better prognosis (4). However, one-third of breast cancers lack ER $\alpha$. These tumors rarely respond to endocrine therapy and are associated with poorer histological differentiation, a higher growth fraction and worse clinical outcome (5). Thus, re-expression of the ER $\alpha$ receptor in breast tumors that do not express ER $\alpha$ could allow their antiestrogen sensitivity to be restored.

Although several sequence mutations for the ER $\alpha$ gene have been identified and shown to be related to decreased ER $\alpha$ expression and estradiol binding, they are uncommon and do not explain the loss of ER $\alpha$ expression in a significant fraction of human breast cancers (6). This finding suggested that mechanisms other than genetic changes might also contribute to the loss of ER $\alpha$ expression. In addition, the absence of ER $\alpha$ protein expression has been frequently associated with loss of ER $\alpha$ transcription (7). The pattern of altered gene expression or epigenetic change is important in common malignancies (8). DNA is methylated by DNA methyltransferases (DNMTs), which transfer the methyl group from S-adenosylmethionine (SAM) to generate patterns of genomic methylation that silence 
gene expression (9-11). To date, the following DNMTs have been identified: DNMT1, DNMT2, DNMT3a, DNMT3b and DNMT3L (12). DNMT1 is mainly responsible for the maintenance of DNA methylation. DNMT1 levels and activity are increased 2- to 10-fold in ER $\alpha$-negative breast cancer cell lines, consistent with the levels of methylation observed (13).

These findings raise the possibility that the absence of $\mathrm{ER} \alpha$ expression is associated with $\mathrm{ER} \alpha$ gene hypermethylation $(14,15)$. Furthermore, inhibition of DNA methylation might be a therapeutic strategy in those cancers with ER $\alpha$-negative phenotypes (16). Two well-characterized and clinically relevant DNMTs inhibitors, 5-aza-2'-cytidine (5-aza-dC) and 5-aza-2'deoxycytidine (5-aza-CdR), have some toxicity and instability due to their incorporation into either DNA or both DNA and RNA in vitro and in vivo. They are also unstable in neutral solutions (17-19). Hence, a nontoxic, highly stable, effective DNMTs inhibitor would be an ideal epigenetic therapeutic agent (20).

Arsenic has been used as a medicinal agent for more than 2,400 years. The National Cancer Institute (NCI) is working cooperatively with research centers across the USA to evaluate the clinical activity of arsenic/arsenic trioxide $\left(\mathrm{As}_{2} \mathrm{O}_{3}\right)$ in hematologic malignancies, such as APL, AML, CML, NHL, HL, CLL, myelodysplastic syndrome and multiple myeloma. The NCI is also supporting research in solid tumors, such as advanced hormone-refractory prostate cancer, renal cell cancer, cervical cancer and refractory transitional cell carcinoma of the bladder (21-23). The results of these ongoing studies should provide important insights into the clinical utility of $\mathrm{As}_{2} \mathrm{O}_{3}$ in these diseases. The emerging consensus is that induction of differentiation and apoptosis are the principal modalities involved in the antitumor effect of $\mathrm{As}_{2} \mathrm{O}_{3}(24,25)$, as well as reactivation of silenced tumor suppressor genes through DNA demethylation $(26,27)$.

Previously, we have confirmed that $\mathrm{As}_{2} \mathrm{O}_{3}$ could restore $\mathrm{ER} \alpha$ re-expression in vitro (28). In this study, we found that $\mathrm{As}_{2} \mathrm{O}_{3}$ treatment inhibited DNMT1 resulting in decreased methylation of the ER $\alpha$ gene and re-expression of ER $\alpha$ in the ER $\alpha$-negative human breast cancer cell line MDA-MB-435s. We also observed increased treatment efficacy of combined tamoxifen (TAM) and $\mathrm{As}_{2} \mathrm{O}_{3}$ therapy in vitro and in vivo.

\section{Materials and methods}

Cell culture and treatment protocols. The human ER $\alpha$-negative MDA-MB-435s and ER $\alpha$-positive MCF-7 breast cancer cell lines (obtained from ATCC) were routinely cultured at $37^{\circ} \mathrm{C}$ in an atmosphere consisting of $5 \% \mathrm{CO}_{2}$ in RPMI-1640 medium (Gibco, USA) supplemented with $10 \%$ heat-inactivated fetal bovine serum (Hyclone, USA). MDA-MB-435s cells were treated with $0,0.5,1,2$ and $4 \mu \mathrm{mol} / 1 \mathrm{As}_{2} \mathrm{O}_{3}$ (Harbin, Iraq) and $10 \mu \mathrm{mol} / 1$ TAM (Sigma, USA) for 24, 48 and 72 h. MCF-7 cells were used as the positive control.

In vivo studies. Six-week-old female BALB/c nude mice (Slaccas, Shanghai, China) were housed in laminar-flow cabinets under specific pathogen-free (SPF) conditions. The study protocol was approved by the ZhengZhou University Medical Experimental Animal Care Committee. Each nude mouse was injected into the left flank with $2 \times 10^{6}$ untreated
MDA-MB-435s human breast cancer cells in $0.2 \mathrm{ml}$ cell culture medium. Tumors were allowed to grow to approximately $0.1 \mathrm{~cm}$ in diameter before treatment. Thirty-six nude mice were randomized into the following six groups: A, negative control group; B, $5 \mathrm{mg} / \mathrm{kg} /$ day TAM group; C, $2 \mathrm{mg} / \mathrm{kg} /$ day $\mathrm{As}_{2} \mathrm{O}_{3}$ group; D, $2 \mathrm{mg} / \mathrm{kg} /$ day $\mathrm{As}_{2} \mathrm{O}_{3}$ combined with $5 \mathrm{mg} / \mathrm{kg} /$ day TAM group; E, 4 mg/kg/day $\mathrm{As}_{2} \mathrm{O}_{3}$ group; and F, $4 \mathrm{mg} / \mathrm{kg} /$ day $\mathrm{As}_{2} \mathrm{O}_{3}$ combined with $5 \mathrm{mg} / \mathrm{kg} /$ day TAM group. TAM $(1 \mathrm{ml})$ was administered orally and $\mathrm{As}_{2} \mathrm{O}_{3}(0.2 \mathrm{ml})$ was administered by intraperitoneal injection, continuously for 28 days. Animals were sacrificed and autopsied at 6 weeks post-inoculation. Once the tumors became palpable, their diameters were measured with a caliper each week after subcutaneous implantation. Tumor volume was calculated according to the equation: Volume $\left(\mathrm{cm}^{3}\right)=\mathrm{LxS}^{2} \mathrm{x} 0.5$. Tumor volumes and weights are presented as mean $\pm \mathrm{SE}$.

MTT assay. MCF-7 and MDA-MB-435s cells were plated in minimal medium at 1,000 cells/well into 96-well plates (Costar, USA). After treatment with the appropriate concentration of $\mathrm{As}_{2} \mathrm{O}_{3}(0,0.5,1,2$ and $4 \mu \mathrm{mol} / \mathrm{l})$ for 24 and $48 \mathrm{~h}$, TAM $(10 \mu \mathrm{mol} / \mathrm{l})$ was added for a further $24 \mathrm{~h}$. Cell viability was measured using the MTT assay. Briefly, the medium was removed and $10 \mu \mathrm{l}$ MTT solutions was added to each well and incubated at $37^{\circ} \mathrm{C}$ for $4 \mathrm{~h}$. Then, $100 \mu \mathrm{l}$ DMSO was added to each well and incubated for a further $15 \mathrm{~min}$. The optical density (OD) was measured at $595 \mathrm{~nm}$. The percentage survival was defined as: $\%$ survival $=100 \% \times$ (OD of test sample $/ O D$ of control). At least three independent experiments were performed for each study.

Methylation-specific PCR (MS-PCR). Genomic DNA samples from both MDA-MB-435s and MCF-7 cells that were either untreated or treated with different concentrations of $\mathrm{As}_{2} \mathrm{O}_{3}$ were isolated using a DNA extraction kit (Axygen, China). Genomic DNA $(1 \mu \mathrm{g})$ was treated with sodium bisulfite using the CpGenome $^{\mathrm{TM}}$ DNA modification kit (Epigentek, USA). Methylation-specific PCR was performed in the thermal cycler (GeneAmp PCR System 9700, ABI, USA). ER $\alpha$ unmethylated DNA was amplified by using 5'-GGG GTT GGA TGT AGT GGT TTA T-3' as the forward primer and 5'-TAA AAC TAC AAA TAC CCA CCA-3' as the reverse primer. ER $\alpha$ methylated DNA was amplified by using 5'-GGG TTG GAC GTA GTG GTT TAC-3' as the forward primer and 5'-AAA ACT ACA AAT ACC CGC CG-3' as the reverse primer. Both the primers amplified a 170-base pair (bp) fragment. PCR amplification of the $\mathrm{ER} \alpha$ gene was carried out as follows: $94^{\circ} \mathrm{C}$ for $5 \mathrm{~min}$, followed by denaturation at $94^{\circ} \mathrm{C}$ for $30 \mathrm{sec}$, annealing at $58^{\circ} \mathrm{C}$ for $45 \mathrm{sec}$, and extension at $72^{\circ} \mathrm{C}$ for $90 \mathrm{sec}$, followed by a final 5 min extension at $94^{\circ} \mathrm{C}$ for 35 cycles. The reaction products were loaded onto $2 \%$ agarose gels containing ethidium bromide and visualized under the Biospectrum 600 imaging system (UVP, USA). The band intensities of the PCR products were analyzed by the UVP VisionWorks LS 6.6a (UVP), and are expressed as the means $\pm \mathrm{SD}$.

RNA isolation and semi-quantitative RT-PCR analysis. Total-RNA was extracted from both MDA-MB-435s and MCF-7 cells that were either untreated or treated with different concentrations of $\mathrm{As}_{2} \mathrm{O}_{3}$ using TRIzol reagent (Gibco-BRL, 
Gaithersburg, MD, USA). RNA purity and concentrations were determined by measuring the A260/A280 absorption. cDNA was synthesized from $1 \mu \mathrm{g}$ of RNA using a Thermoscript reverse transcriptase (RT-PCR) System (Fermentas, Canada). ER $\alpha$ mRNA was amplified by using 5'-TGA TGA AAG GTG GGA TAC GAA A-3' as the forward and 5'-GGC TGT TCT TCT TAG AGC GTT TG-3' as the reverse primer. DNMT1 mRNA was amplified by using 5'-CTA CCA GGG AGA AGG ACA GG-3' as the forward and 5'-CTC ACA GAC GCC ACA TCG-3' as the reverse primer. $\beta$-actin mRNA was amplified by using 5'-AGG CAT TGT GAT GGA CTC CG-3' as the forward and 5'-AGT GAT GAC CTG GCC GTC AG-3' as the reverse primer. $\beta$-actin was used as an internal control. The primer pair amplified a 168-base pair (bp) fragment as ER $\alpha$, a 152-bp fragment as DNMT1, and a 301-bp fragment as $\beta$-actin. PCR was performed in the thermal cycler (GeneAmp PCR System 9700, ABI) for 35 cycles consisting of denaturation at $94^{\circ} \mathrm{C}$ for $30 \mathrm{sec}$, annealing at $65^{\circ} \mathrm{C}(\beta$-actin) for $45 \mathrm{sec}$ or $54^{\circ} \mathrm{C}(\mathrm{ER} \alpha, \mathrm{DNMT} 1)$ for $30 \mathrm{sec}$, and extension at $72^{\circ} \mathrm{C}$ for $90 \mathrm{sec}$, followed by a final 5 -min extension at $94^{\circ} \mathrm{C}$. The reaction products were loaded onto $1.5 \%$ agarose gels containing ethidium bromide and visualized under the Biospectrum 600 imaging system. The band intensities of the PCR products were analyzed using the UVP VisionWorks LS 6.6a, and are expressed as the means $\pm \mathrm{SD}$.

Immunohistochemistry. MDA-MB-435s and MCF-7 cells, untreated or treated with different concentrations of $\mathrm{As}_{2} \mathrm{O}_{3}$, were cultured in 24-well chamber slides (Corning, USA) for $48 \mathrm{~h}$, then fixed in $2 \%$ paraformaldehyde for $30 \mathrm{~min}$ at room temperature. The cells were permeabilized with PBS containing $0.2 \%$ Triton X-100 for $10 \mathrm{~min}$ at room temperature. Endogenous peroxidase activity was blocked by incubation with $0.03 \%$ hydrogen peroxide in methanol for $5 \mathrm{~min}$. Sections were incubated with a monoclonal mouse anti-ER $\alpha$ antibody (Abcam, UK) for $30 \mathrm{~min}$ at room temperature. Sections were gently rinsed three times with washing buffer, then incubated with the peroxidase-labeled polymer conjugated to goat anti-mouse IgG for 30 min followed by staining with 3,3'-diaminobenzidine tetrahydrochloride (DAB) for $5 \mathrm{~min}$. Samples were counterstained with hematoxylin, dehydrated and mounted in Diatex. A known ER $\alpha$-positive cell line MCF-7 was used as a positive control while the same concentration of non-immune mouse $\mathrm{IgG}$ was applied as the negative control. All controls gave satisfactory results. Paraffin sections $(4 \mu \mathrm{m})$ of the transplanted tumor tissues were dewaxed and stained as described above. ER $\alpha$-positive staining was seen as light-yellow to brown granules, and mainly located in the cytoplasm and nuclei.

Western blot analysis. Equal amounts of protein sample $(20 \mu \mathrm{g})$ were separated on $4 \%$ SDS acrylamide gel (Bio-Rad, USA) for $0.5 \mathrm{~h}$ at $60 \mathrm{~V}$ and $10 \%$ SDS acrylamide gel for $1.5 \mathrm{~h}$ at $150 \mathrm{~V}$. The samples were then transferred onto a nitrocellulose membrane for $1.5 \mathrm{~h}$ at $60 \mathrm{~V}$ (Whatman, UK). After blocking in 5\% fat-free milk, the membrane was incubated with the primary antibody (anti-ER $\alpha$ mouse monoclonal antibody, Abcam, 1:500; anti-DNMT1 mouse monoclonal antibody, Abcam, 1:500) overnight at $4^{\circ} \mathrm{C}$, followed by incubation with the secondary IgG-horseradish peroxidase (HRP)-conjugated antibody for $1 \mathrm{~h}$ at room temperature (1:5,000). The antibody

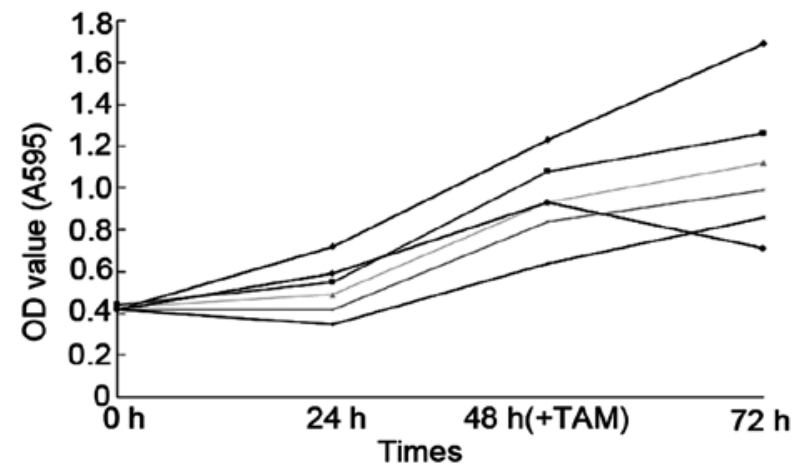

$-0.0 \mu \mathrm{mol} / \mathrm{L} \mathrm{As}_{2} \mathrm{O}_{3} \rightarrow-0.5 \mu \mathrm{mol} / \mathrm{L} \mathrm{As}_{2} \mathrm{O}_{3} \rightarrow-1.0 \mu \mathrm{mol} / \mathrm{L} \mathrm{As}_{2} \mathrm{O}_{3}$

$-2.0 \mu \mathrm{mol} / \mathrm{L} \mathrm{As}_{2} \mathrm{O}_{3}-4.0 \mu \mathrm{mol} / \mathrm{L} \mathrm{As}_{2} \mathrm{O}_{3}$ - - Control (MCF-7)

Figure 1. Treatment with $\mathrm{As}_{2} \mathrm{O}_{3}$ significantly suppresses cell proliferation in ER $\alpha$-negative MDA-MB-435s cells. The MTT assay was used to measure the cell viability of MDA-MB-435s cells after treatment with $\mathrm{As}_{2} \mathrm{O}_{3}$ followed by tamoxifen (TAM). MCF-7 cells, which express ER $\alpha$, served as the control.

was diluted in PBS containing 5\% Blotto (Santa Cruz Biotechnology, USA) and $0.1 \%$ Tween-20. The stained membranes were visualized by enhanced chemiluminescence reaction using the ECL Plus kit (GE Healthcare, USA). The mouse monoclonal $\beta$-actin antibody (Abcam) was used as the loading control for Western blot analysis at a dilution of 1:1000. The band intensities of the PCR products were analyzed using the UVP VisionWorks LS 6.6a (UVP), and are expressed as the means $\pm \mathrm{SD}$

Statistical analysis. For all experiments, data are presented as the mean \pm SD. Significance between groups was determined by one-way analysis of variance followed by the Bonferroni multiple-comparisons test. In all comparisons, differences were considered to be significant at $\mathrm{P}<0.05$ and all $\mathrm{P}$-values were two-sided.

\section{Results}

Treatment with $\mathrm{As}_{2} \mathrm{O}_{3}$ and TAM significantly suppress cell proliferation in ER $\alpha$-negative MDA-MB-435s cells. The MTT assay showed that the level of proliferation in the ER $\alpha$-negative MDA-MB-435s cell line was significantly suppressed after treatment with different concentrations of $\mathrm{As}_{2} \mathrm{O}_{3}$ for 24 and $48 \mathrm{~h}(\mathrm{P}<0.05)$ (Fig. 1). Addition of TAM for an additional $24 \mathrm{~h}$ led to further suppression of MDA-MB-435s proliferation (Fig. 1). The effects of TAM on MDA-MB-435s cells treated with $\mathrm{As}_{2} \mathrm{O}_{3}$ were not greater than the effects observed in the control ER $\alpha$-positive MCF-7 cell line, suggesting that ER $\alpha$ was re-expressed in MDA-MB-435s cells but at lower levels to MCF-7 cells.

$\mathrm{As}_{2} \mathrm{O}_{3}$ treatment decreases DNMT1-dependent methylation of the ERa gene and restores $m R N A$ expression. Assessment of the methylation status of the $\mathrm{ER} \alpha \mathrm{CpG}$ islands in MDA-MB435s and MCF-7 cells revealed that they were hypermethylated and unmethylated, respectively, with a corresponding absence and presence of ER $\alpha$ mRNA expression (Figs. 2A and 3B). After treatment of MDA-MB-435s cells with different concentrations of $\mathrm{As}_{2} \mathrm{O}_{3}(1.0,2.0$ and $4.0 \mu \mathrm{mol} / \mathrm{l})$ for $48 \mathrm{~h}$, we observed 

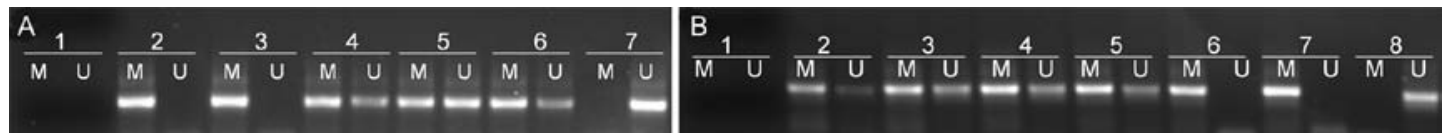

Figure 2. $\mathrm{As}_{2} \mathrm{O}_{3}$ treatment decreases methylation of the ER $\alpha$ gene in vitro and in vivo. (A) The methylation status of the ER $\alpha$ gene was examined in MDAMB-435s and MCF-7 cells by MSP analysis. The lanes are as follows: 1, water control for contamination in the PCR reaction; 2-6, MDA-MB-435s cells treated with 0 (lane 2), 0.5 (lane 3), 1.0 (lane 4), 2.0 (lane 5) and $4.0 \mu \mathrm{mol} / 1 \mathrm{As}_{2} \mathrm{O}_{3}$ (lane 6); 7, MCF-7 cells (control). M, methylated band (170 bp); U, unmethylated band (170 bp). (B) MSP analysis of ER $\alpha$ in transplanted tumor and ER $\alpha$-positive breast cancer tissue. The lanes are as follows: 1, water control for contamination in the PCR reaction; 2, treatment with $2 \mathrm{mg} / \mathrm{kg} / \mathrm{day} \mathrm{As}_{2} \mathrm{O}_{3} ; 3$, treatment with $2 \mathrm{mg} / \mathrm{kg} / \mathrm{day} \mathrm{As}_{2} \mathrm{O}_{3}+$ tamoxifen (TAM); 4, treatment with

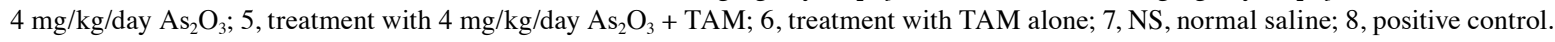

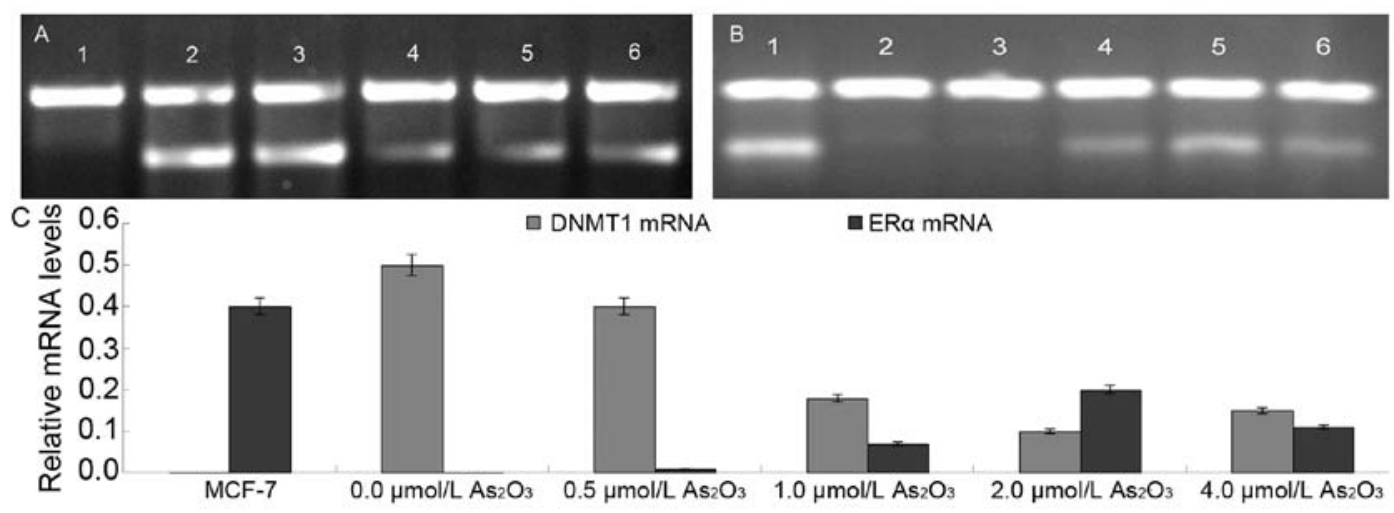

Figure 3. Effect of $\mathrm{As}_{2} \mathrm{O}_{3}$ treatment of MDA-MB-435s cells on ER $\alpha$ and DNMT1 mRNA expression levels. mRNA expression of (A) DNMT1 (152 bp) and (B) $\mathrm{ER} \alpha(168 \mathrm{bp}$ ). The lanes are as follows: 1, MCF-7 cells; 2-6, MDA-MB-435s cells treated with 0 (lane 2), 0.5 (lane 3), 1.0 (lane 4), 2.0 (lane 5) and $4.0 \mu \mathrm{mol} / 1 \mathrm{As}_{2} \mathrm{O}_{3}$ (lane 6). (C) The relative mRNA expression levels of DNMT1 and ER $\alpha$. Semiquantitative values of three independently repeated RT-PCR experiments were statistically analyzed by densitometry using VisionWorks LS 6.6a, and are expressed as means \pm SD. P $<0.05$ compared to the untreated group.
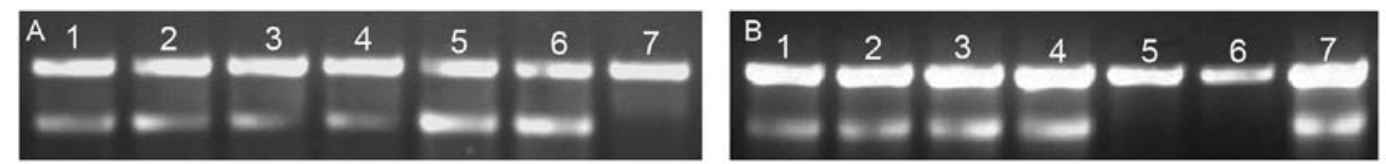

$$
\text { C }
$$
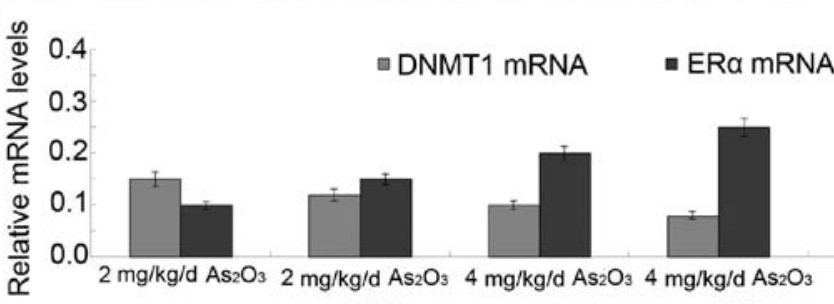

+ TAM

+ TAM
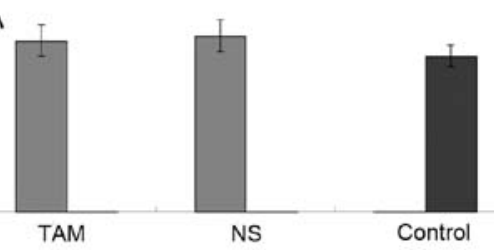

Figure 4. Effect of $\mathrm{As}_{2} \mathrm{O}_{3}$ and tamoxifen (TAM) treatment of xenografted tumors on ER $\alpha$ and DNMT1 mRNA expression levels. (A and B) mRNA expression of (A) DNMT1 (152 bp) and (B) ER $\alpha$ (168 bp). The lanes are as follows: $1,2 \mathrm{mg} / \mathrm{kg} / \mathrm{day} \mathrm{As} \mathrm{O}_{3} ; 2,2 \mathrm{mg} / \mathrm{kg} / \mathrm{day} \mathrm{As} \mathrm{As}_{2}+\mathrm{TAM} ; 3,4 \mathrm{mg} / \mathrm{kg} / \mathrm{day} \mathrm{As} \mathrm{O}_{3} ; 4,4 \mathrm{mg} / \mathrm{kg} / \mathrm{day}$ $\mathrm{As}_{2} \mathrm{O}_{3}+$ TAM; 5, TAM alone; 6, NS; 7, positive control. (C) The relative mRNA levels of DNMT1 and ER $\alpha$. Semiquantitive values of three independently repeated RT-PCR experiments were statistically analyzed by densitometry using VisionWorks LS 6.6a, and are expressed as means \pm SD. P $<0.05$ compared to the untreated group.

a decrease in the ER $\alpha$ methylation-specific bands. In contrast, the unmethylation-specific bands were enhanced. In addition, we found that the hypermethylation status of MDA-MB-435s cells treated with 0 or $0.5 \mu \mathrm{mol} / 1 \mathrm{As}_{2} \mathrm{O}_{3}$ cells remained unchanged (Fig. 2A). Furthermore, the re-expression of ER $\alpha$ mRNA was increased in a concentration-dependent manner (Fig. 3B and C). We also found that the marked increase in ER $\alpha$ mRNA levels was accompanied by a significant reduction in DNMT1 mRNA levels compared with the untreated control group $(\mathrm{P}<0.05)$ (Fig. 3A and $\mathrm{C})$. DNMT1 mRNA was not expressed in MCF-7 cells (Fig. 3A and C). ER $\alpha$ mRNA was not expressed in MDA-MB-435s cells treated with 0 and
$0.5 \mu \mathrm{mol} / 1 \mathrm{As}_{2} \mathrm{O}_{3}$ (Fig. 3B and C) Similar findings were observed in the transplanted tumor tissues treated with or without $\mathrm{As}_{2} \mathrm{O}_{3}(\mathrm{P}<0.05)$ (Figs. 2B, 4A and B). Surprisingly, ER $\alpha$ mRNA expression was lower in cells treated with 4 than with $2 \mu \mathrm{mol} / 1 \mathrm{As}_{2} \mathrm{O}_{3}$ in vitro (Fig. 3B and C).

$\mathrm{As}_{2} \mathrm{O}_{3}$ treatment significantly enhances ER $\alpha$ expression in $M D A-M B-435$ s cells. We examined the effects of $\mathrm{As}_{2} \mathrm{O}_{3}$ on $\mathrm{ER} \alpha$ gene expression by immunohistochemistry in vitro (Fig. 5) and in vivo (Fig. 6). Loss of ER $\alpha$ expression was observed in untreated MDA-MB-435s cells. In contrast, a significant increase in nuclear immunostaining of ER $\alpha$ was induced in 

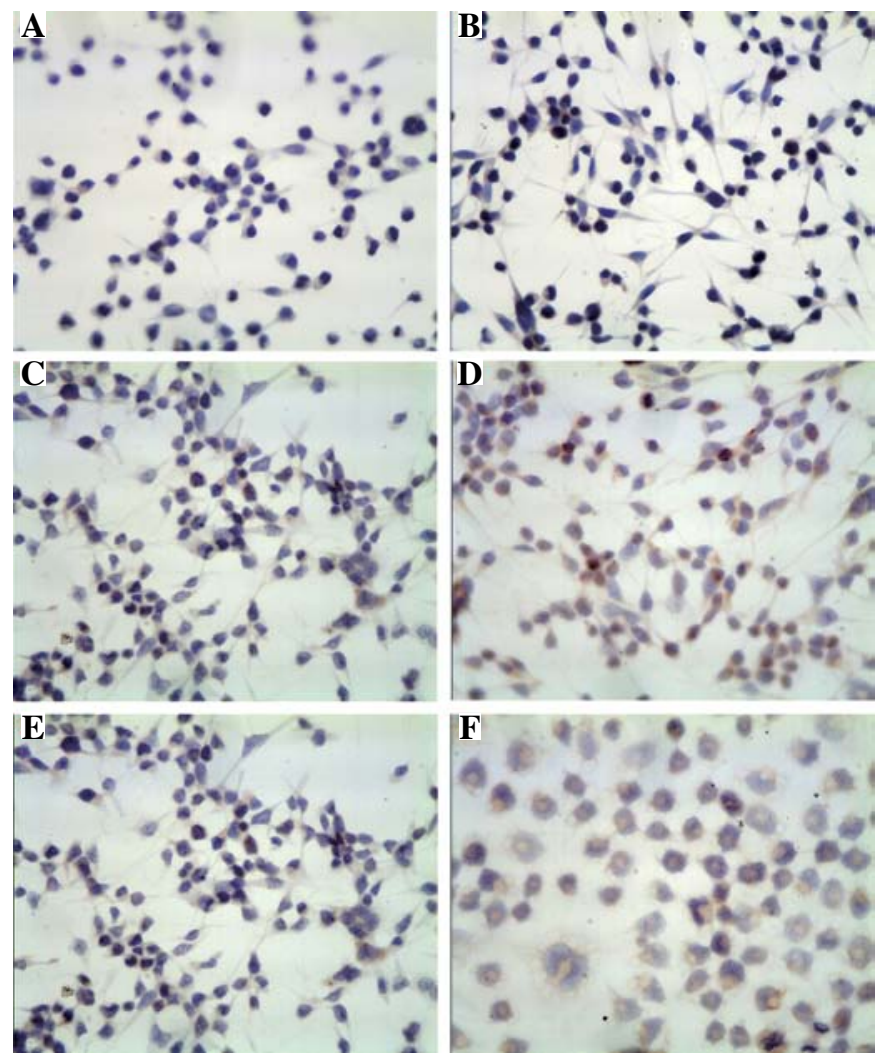

Figure 5. Immunohistochemical analysis of the re-expression of ER $\alpha$ protein in MDA-MB-435S cells after treatment with $\mathrm{As}_{2} \mathrm{O}_{3}$. (A-E) MDA-MB-435S cells were treated with (A) 0 , (B) 0.5 , (C) 1.0 , (D) 2.0 and (E) $4.0 \mu \mathrm{mol} / 1$ $\mathrm{As}_{2} \mathrm{O}_{3}$; (F) MCF-7 cells. (x400).
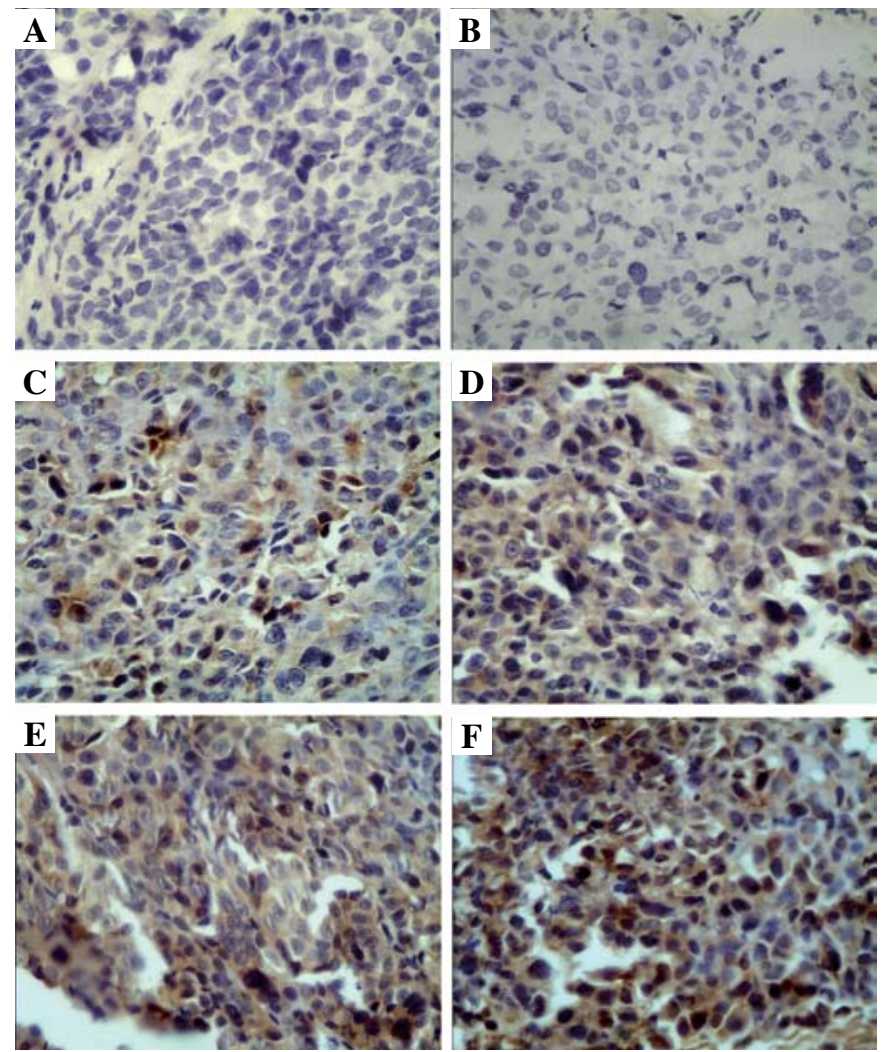

Figure 6. Immunohistochemical analysis of the re-expression of ER $\alpha$ protein in xenografted tumors after treatment with $\mathrm{As}_{2} \mathrm{O}_{3}$ and tamoxifen (TAM). (A) NS; (B) TAM alone; (C) $2 \mathrm{mg} / \mathrm{kg} /$ day $\mathrm{As}_{2} \mathrm{O}_{3}$; (D) $2 \mathrm{mg} / \mathrm{kg} / \mathrm{day} \mathrm{As}_{2} \mathrm{O}_{3}+\mathrm{TAM}$; (E) $4 \mathrm{mg} / \mathrm{kg} /$ day $\mathrm{As}_{2} \mathrm{O}_{3}$; (F) $4 \mathrm{mg} / \mathrm{kg} / \mathrm{day} \mathrm{As}_{2} \mathrm{O}_{3}+\mathrm{TAM}$.

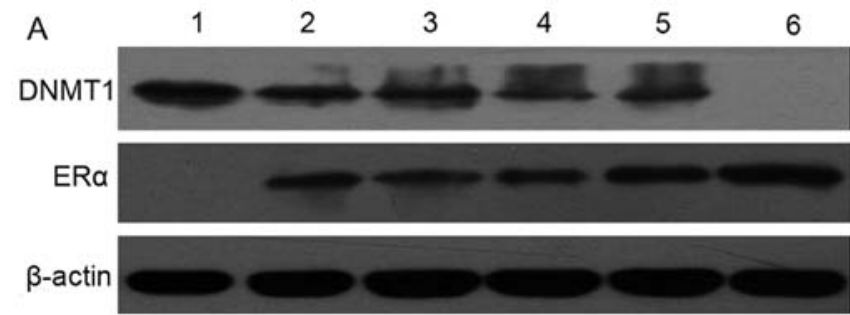

B

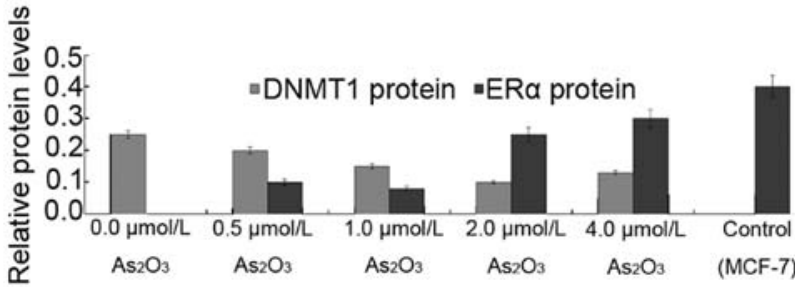

Figure 7. Western blot analysis of DNMT1 (183 kDa) and ER $\alpha(67 \mathrm{kDa})$ protein levels in MDA-MB-435s cells after treatment with different concentrations of $\mathrm{As}_{2} \mathrm{O}_{3}$. (A) Lanes: 1-5, MDA-MB-435s cells treated with 0 (lane 1), 0.5 (lane 2), 1.0 (lane 3), 2.0 (lane 4) and $4.0 \mathrm{As}_{2} \mathrm{O}_{3}$ (lane 5); 6 , MCF-7 cells. (B) Semiquantitive values of three independently repeated Western blot analyses were statistically analyzed by densitometry using VisionWorks LS 6.6a, and are expressed as the means \pm SD. $\mathrm{P}<0.05$ compared to the untreated group. Levels of $\beta$-actin $(43 \mathrm{kDa})$ are shown for equal loading conditions.

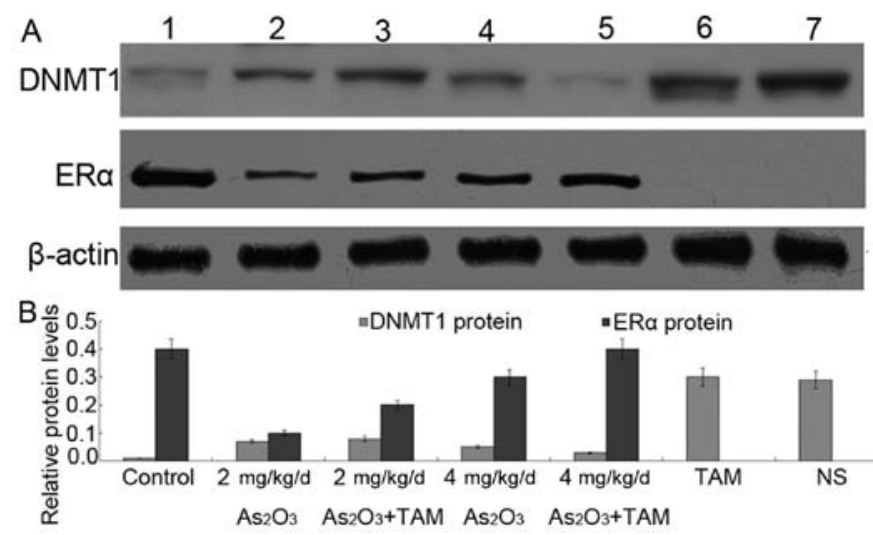

Figure 8. Western blot analysis of DNMT1 (183 kDa) and ER $(67 \mathrm{kDa})$ protein levels in xenografted tumors after treatment with $\mathrm{As}_{2} \mathrm{O}_{3}$ and tamoxifen (TAM). (A) Lanes: 1, positive control; $2,2 \mathrm{mg} / \mathrm{kg} /$ day $\mathrm{As}_{2} \mathrm{O}_{3} ; 3,2 \mathrm{mg} / \mathrm{kg} /$ day $\mathrm{As}_{2} \mathrm{O}_{3}+\mathrm{TAM} ; 4,4 \mathrm{mg} / \mathrm{kg} /$ day $\mathrm{As}_{2} \mathrm{O}_{3} ; 5,4 \mathrm{mg} / \mathrm{kg} /$ day $\mathrm{As}_{2} \mathrm{O}_{3}$ + TAM; 6, TAM alone; 7, NS. (B) Semiquantitive values of three independently repeated Western blot analyses were statistically analyzed by densitometry using VisionWorks LS 6.6a, and are expressed as the means $\pm \mathrm{SD}$. $\mathrm{P}<0.05$ compared to the untreated group. Levels of $\beta$-actin (43 kDa) are shown for equal loading conditions.

MDA-MB-435s cells treated with different concentrations of $\mathrm{As}_{2} \mathrm{O}_{3}(0.5,1,2$ and $4 \mu \mathrm{mol} / \mathrm{l})$. MCF-7 cells served as the positive control (Fig. 5). In vivo, the immunostaining of $\mathrm{ER} \alpha$ was also dramatically enhanced in all $\mathrm{As}_{2} \mathrm{O}_{3}$ treatment groups and stronger staining was observed after combined treatment with $\mathrm{As}_{2} \mathrm{O}_{3}$ and TAM. No ER $\alpha$ staining was observed in the negative control and TAM-treatment alone groups (Fig. 6).

$\mathrm{As}_{2} \mathrm{O}_{3}$ treatment of MDA-MB-435s cells increases ER $\alpha$ and decreases DNMT1 protein expression levels. Western blot analysis revealed that the re-expression of ER $\alpha$ protein was markedly increased after treatment with different concentrations 

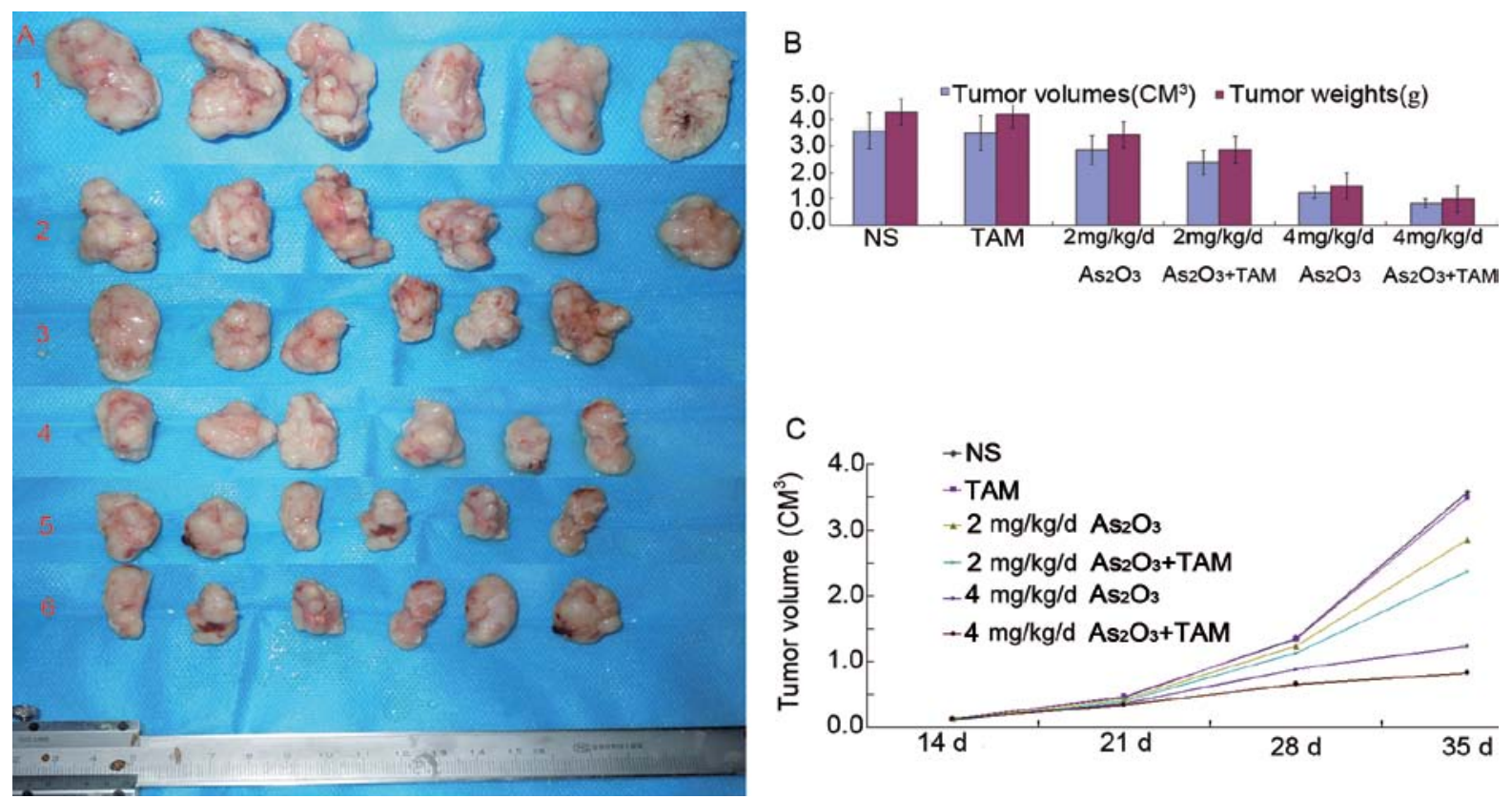

Figure 9. Effect of $\mathrm{As}_{2} \mathrm{O}_{3}$ treatment alone or in combination with tamoxifen (TAM) on tumor growth in nude mice. (A) Micrograph of the tumors at 35 days 1, NS; 2, TAM alone; 3, $2 \mathrm{mg} / \mathrm{kg} / \mathrm{day} \mathrm{As} \mathrm{O}_{3} ; 4,2 \mathrm{mg} / \mathrm{kg} / \mathrm{day} \mathrm{As} \mathrm{O}_{2}+\mathrm{TAM} ; 5,4 \mathrm{mg} / \mathrm{kg} / \mathrm{day} \mathrm{As} \mathrm{O}_{3} ; 6,4 \mathrm{mg} / \mathrm{kg} / \mathrm{day} \mathrm{As}_{2} \mathrm{O}_{3}$ + TAM. (B) The tumor volumes and weights of all groups are presented as the mean $\pm \mathrm{SD}(\mathrm{P}<0.05)$. (C) The growth curves of the tumors of all groups of nude mice.

of $\mathrm{As}_{2} \mathrm{O}_{3}(0.5,1,2$ and $4 \mu \mathrm{mol} / \mathrm{l})$ in a concentration-dependent manner (Fig. 7). This was accompanied by a significant reduction in DNMT1 protein expression compared with the untreated control (Fig. 7) $(\mathrm{P}<0.05)$. DNMT1 protein expression was not observed in MCF-7 cells. This phenomenon was also observed in vivo: $\mathrm{ER} \alpha$ protein was re-expressed in the $\mathrm{As}_{2} \mathrm{O}_{3}$-treated mice (Fig. 8). Significantly increased re-expression of ER $\alpha$ protein was also observed in mice treated with a combination of $\mathrm{As}_{2} \mathrm{O}_{3}$ and TAM $(\mathrm{P}<0.05)$. ER $\alpha$ re-expression was not observed in untreated mice and in mice treated with TAM alone (Fig. 8). Surprisingly, ER $\alpha$ protein levels were lower in the $4 \mu \mathrm{mol} / 1$ group than in the $2 \mu \mathrm{mol} / 1$ group in vitro, but higher after combined treatment with TAM in vivo $(\mathrm{P}<0.05)$.

Combined treatment with $\mathrm{As}_{2} \mathrm{O}_{3}$ and TAM inhibits tumor growth in human breast cancer xenografts in nude mice. An obvious decrease in the volumes and weights of tumors in the $\mathrm{As}_{2} \mathrm{O}_{3}$-treated group compared with the untreated group was observed in human breast cancer xenografts in nude mice. A further reduction in tumor size was observed after combined treatment of $\mathrm{As}_{2} \mathrm{O}_{3}$ with TAM compared to the untreated and TAM-treatment alone groups $(\mathrm{P}<0.05)$ (Fig. 9).

\section{Discussion}

In industrialized countries, breast cancer is the most common type of cancer among women and the leading cause of death among women aged 40 to 55 years. Considering the current estimates of the incidence of breast cancer, a woman living in the USA today has approximately a one in eight chance of developing breast cancer during her lifetime $(1,29)$.

Decades of research have led to considerable understanding of the factors involved in the development of breast cancer, However, it has become clear in recent years that epigenetic regulation is another mechanism (rather than loss of hetero- zygosity or homozygous deletion) that leads to transcriptional silencing. Epigenetic changes differ from genetic changes as they are not based upon a change in primary DNA sequence. They arise at a higher frequency, are reversible upon treatment with pharmacological agents and occur at defined regions within a gene (30).

The human ER $\alpha$ cDNA and gene were cloned in 1986. This $140 \mathrm{~kb}$ ER $\alpha$ gene has eight exons and is located on chromosome 6q25.1 (31). Numerous experimental and clinical studies have established that estrogen plays a major role in the initiation and progression of breast cancer (32). Approximately one third of breast cancers lack detectable ER $\alpha$ protein and are rarely responsive to hormonal treatment (33). Thus, many studies have focused on elucidating the possible molecular genetic mechanisms that mediate the loss of ER $\alpha$ expression in breast cancer.

Interestingly, the $\mathrm{ER} \alpha$ gene has a $\mathrm{CpG}$ island in its promoter and first exon regions, which are marked by a clustering of sites responsive to methylation-sensitive restriction endonucleases (34). This mechanism has been most extensively studied in breast cancer cell lines and tissues to explain the loss of ER $\alpha$ expression. Studies have consistently demonstrated that, whereas normal breast tissues and ER $\alpha$-positive breast cancer cell lines lack methylation of the ER gene, ER-negative breast cancer cell lines and tumors display extensive methylation $(5,13)$. These new findings suggest that epigenetic changes might play a crucial role in ER gene inactivation.

Arsenic compounds have been used as medicinal agents for many centuries. The detailed mechanisms of $\mathrm{As}_{2} \mathrm{O}_{3}$ induced cytotoxicity include cellular differentiation, induction of apoptosis, degradation of specific APL transcripts, inhibition of proliferation and inhibition of angiogenesis (35). Inorganic arsenic is known to be enzymatically metabolized to monomethylated and dimethylated arsenics in mammals (27). Thus, cells continuously exposed to arsenic would produce 
greater quantities of S-adenosylhomocysteine (SAH). SAH is an effective competitive inhibitor of DNMTs (36). In fact, a low concentration of $\mathrm{As}_{2} \mathrm{O}_{3}$ significantly suppressed the activity of DNMTs.

In our study, we observed that after treatment of MDA-MB$435 \mathrm{~s}$ cells with different concentrations of $\mathrm{As}_{2} \mathrm{O}_{3}(1.0,2.0$ and $4.0 \mu \mathrm{mol} / \mathrm{l}$ ) for $48 \mathrm{~h}$, the methylation-specific bands of the $\mathrm{ER} \alpha$ gene were decreased. In contrast, the unmethylationspecific bands were enhanced. This phenomenon was also observed in the transplanted tumor tissues. We also found that the marked increase in ER $\alpha$ mRNA levels was accompanied by a significant reduction in DNMT1 mRNA levels. Similar results were obtained for ER $\alpha$ and DNMT1 protein levels using immunohistochemical and Western blot analyses. In addition, the re-expression of $\mathrm{ER} \alpha \mathrm{mRNA}$ and protein was increased in a concentration-dependent manner. Surprisingly, we found that the expression of $\mathrm{ER} \alpha$ in the $4 \mu \mathrm{mol} / \mathrm{L} \mathrm{As}_{2} \mathrm{O}_{3}$ treated group was lower than in the $2 \mu \mathrm{mol} / 1 \mathrm{As}_{2} \mathrm{O}_{3}$-treated group in vitro but higher after combined treatment with TAM in vivo $(\mathrm{P}<0.05)$. We hypothesize that $\mathrm{As}_{2} \mathrm{O}_{3}$ has an effect on gene restoration at relatively low concentrations $(2 \mu \mathrm{mol} / 1)$, but at higher concentrations $\mathrm{As}_{2} \mathrm{O}_{3}$ inhibits $\mathrm{ER} \alpha$ gene expression with severe cytotoxicity. Although the possible mechanism of in vitro toxicity with the higher concentration of $\mathrm{As}_{2} \mathrm{O}_{3}$ is unclear, it is clear that the cells are unable to efficiently metabolize arsenic. These data indicate that high concentrations of $\mathrm{As}_{2} \mathrm{O}_{3}$ have the ability to cause significant cytotoxicity, and thus, can only be used at a relatively low concentration to reactivate silenced tumor suppressor genes (28).

We observed that the TAM-unresponsive MDA-MB-435 cells restored their response to TAM after the re-expression of functional ER $\alpha$ following $\mathrm{As}_{2} \mathrm{O}_{3}$ treatment. Furthermore, we found that the extent of growth suppression was parallel to the $\mathrm{ER} \alpha$ re-expression level. These findings indicated that the re-expression of ER $\alpha$ might at least partially mediate the inhibitory effects of TAM on tumor growth. However, there may be other mechanisms involved in this pathway. We also hypothesize that TAM has synergism with $\mathrm{As}_{2} \mathrm{O}_{3}$, since TAM enhanced the inhibition of tumor growth when used in combination with $\mathrm{As}_{2} \mathrm{O}_{3}$. Differences in the effects of different $\mathrm{As}_{2} \mathrm{O}_{3}$ concnetrations in vivo and in vitro are probably due to the complexities associated with in vivo studies. Surprisingly, partial hypermethylation of the $\mathrm{ER} \alpha \mathrm{CpG}$ island was maintained even at high concentrations of $\mathrm{As}_{2} \mathrm{O}_{3}$ and when combined with TAM. Even so, the partial demethylation of the ER $\alpha$ gene coincided with decreased DNMT1 expression, suggesting a causal link.

In summary, we demonstrated that functional $\mathrm{ER} \alpha$ could be re-expressed in ER $\alpha$-negative breast cancer cells following treatment with $\mathrm{As}_{2} \mathrm{O}_{3}$. In addition, treatment with $\mathrm{As}_{2} \mathrm{O}_{3}$ restored sensitivity to TAM treatment both in vitro and in vivo, and may therefore provide a novel therapeutic approach for $\mathrm{ER} \alpha$-negative breast cancer patients in clinical practice.

\section{Acknowledgements}

This research was supported by a Henan Science and Technology Committee grant (no. JB02)0524410092 and the State Key Basic Research Development Program of China (nos. 2004CB518701 and 2009CB521803).

\section{References}

1. Jemal A, Siegel R, Xu JQ and Ward E: Cancer statistics, 2010 CA Cancer J Clin 60: 277-300, 2010.

2. Gruber CJ, Tschugguel W, Schneeberger C, and Huber JC: Production and actions of estrogens. N Engl J Med 346: 340-352, 2002.

3. Champagne FA and Curley JP: Maternal regulation of estrogen receptor alpha methylation. Curr Opin Pharmacol 8: 735-739, 2008.

4. Clark GM and McGuire WL: Steroid receptors and other prognostic factors in primary breast cancer. Semin Oncol 15: 20-25, 1988.

5. Lapidus RG, Nass SJ, Butash KA, et al: Mapping of ER gene $\mathrm{CpG}$ island methylation by methylation-specific polymerase chain reaction. Cancer Res 58: 2515-2519, 1998.

6. Lapidus RG, Nass SJ and Davidson NE: The loss of estrogen and progesterone receptor gene expression in human breast cancer. J Mammary Gland Biol Neoplasia 3: 85-94, 1998.

7. Weigel RJ and Deconinck EC: Transcriptional control of estrogen receptor in estrogen receptor- negative breast carcinoma. Cancer Res 53: 3472-3474, 1993.

8. Baylin SB and Ohm JE: Epigenetic gene silencing in cancer-a mechanism for early oncogenic pathway addiction? Nat Rev Cancer 6: 107-116, 2006.

9. Ross SA: Diet and DNA methylation interactions in cancer prevention. Ann NY Acad Sci 983: 197-207, 2003.

10. Brenner C and Fuks F: DNA methyltransferases: facts, clue, mysteries. Curr Top Microbiol Immunol 301: 45-66, 2006.

11. Gopisetty G, Ramachandran K and Singal R: DNA methylation and apoptosis. Mol Immunol 43: 1729-1740, 2006.

12. Singal R and Ginder GD: DNA methylation. Blood 93: 4059-4070, 1999.

13. Ottaviano YL, Issa JP, Parl FF, Smith HS, Baylin SB and Davidson NE: Methylation of the estrogen receptor gene CpG island marks loss of estrogen receptor expression in human breast cancer cells. Cancer Res 54: 2552-2555, 1994.

14. Agrawal A, Murphy RF and Agrawal DK: DNA methylation in breast and colorectal cancers. Mod Pathol 20: 711-721, 2007.

15. Yan L, Yang XW, and Davidson NE: Role of DNA methylation and histone acetylation in steroid receptor expression in breast cancer. J Mammary Gland Biol Neoplasia 6: 183-192, 2001.

16. Jung Y, Park J, Kim TY, et al: Potential advantages of DNA methyltransferase 1 (DNMT1)-targeted inhibition for cancer therapy. J Mol Med 85: 1137-1148, 2007.

17. Beisler JA: Isolation, characterization, and properties of a labile hydrolysis product of the antitumor nucleoside, 5-azacytidine. J Med Chem 21: 204-208, 1978.

18. Constantinides PG, Jones PA and GeversW: Functional striated muscle cells from non-myoblast precursors following 5-azacytidine treatment. Nature 267: 364-366, 1977.

19. Datta J, Ghoshal K, Denny WA, et al: A new class of quinolinebased DNA hypomethylating agents reactivates tumor suppressor genes by blocking DNA methyltransferase 1 activity and inducing its degradation. Cancer Res 69: 4277-4285, 2009.

20. Billam M, Sobolewski MD, and Davidson NE: Effects of a novel DNA methyltransferase inhibitor zebularine on human breast cancer cells. Breast Cancer Res Treat 120: 581-592, 2010.

21. Novick SC and Warrell Jr RP: Arsenicals in hematologic cancers. Semin Oncol 27: 495-501, 2000.

22. Uslu R, Sanli UA, Sezgin C, et al: Arsenic trioxide-mediated cytotoxicity and apoptosis in prostate and ovarian carcinoma cell lines. Clin Cancer Res 6: 4957-4964, 2000.

23. Murgo AJ: Clinical trials of arsenic trioxide in hematologic and solid tumors: overview of the National Cancer Institute cooperative research and development studies. Oncologist 6: 22-28, 2001.

24. Han YH, Moon HJ, You BR, Kim SZ, Kim SH and Park WH: The effect of MAPK inhibitors on arsenic trioxide-treated calu-6 lung cells in relation to cell death, ROS and GSH levels. Anticancer Res 29: 3837-3844, 2009.

25. Shao W, Fanelli M, Ferrara FF, et al: Arsenic trioxide as an inducer of apoptosis and loss of PML/RAR alpha protein in acute promyelocytic leukemia cells. J Natl Cancer Inst 90: 124-133, 1998.

26. Cui X, Wakai T, Shirai Y, Yokoyama N, Hatakeyama K and Hirano S: Arsenic trioxide inhibits DNA methyltransferase and restores methylation-silenced genes in human liver cancer cells. Human Pathology 37: 298-311, 2006.

27. Miller WH Jr, Schipper HM, Lee JS, Singer J and Waxman S: Mechanisms of action of arsenic trioxide. Cancer Res 62: 3893-3903, 2002. 
28. Wang B, Wang JX, Fan QX, Zhao PR, Wang RL and Wang LX The primary study of the expression of ER $\alpha$ induced by arsenic trioxide in vitro. J Basic Clin Oncology 3: 183-184, 2006.

29. American Cancer Society, Surveillance Research, 2007: Breast Cancer Facts and Figures 2007-2008, http://www.cancer.org/ downloads/STT/BCFFFinal.pdf.

30. Widschwendter $M$ and Jone PA: DNA methylation and breast carcinogenesis. Oncogene 21: 5462-5482, 2002.

31. Ponglikitmonkol M, Green S and Chambon P: Genomic organization of the human oestrogen receptor gene. EMBO J 7: 3385-3388, 1988

32. Henderson BE, Ross R and Bernstein L: Estrogens as a cause of human cancer: the Richard and Hinda Rosenthal Foundation award lecture. Cancer Res 48: 246-253, 1988.
33. Katzenellebogen BS: Antiestrogen resistance: mechanisms by which breast cancer cells undermine the effectiveness of endocrine therapy. J Natl Cancer Inst 83: 1434-1435, 1991.

34. Piva R, Gambari R, Zorzato F, Kumar L and del Senno L: Analysis of upstream sequences of the human estrogen receptor gene. Biochem Biophys Res Commun 183: 996-1002, 1992.

35. Evens AM, Tallman MS and Gartenhaus RB: The potential of arsenic trioxide in the treatment of malignant disease: past, present, and future. Leuk Res 28: 891-900, 2004.

36. Sciandrello G, Caradonna F, Mauro M and Barbata G: Arsenicinduced DNA hypomethylation affects chromosomal instability in mammalian cells. Carcinogenesis 25: 413-417, 2004. 